\title{
APLIKASI ENSIKLOPEDIA LAGU DAN TARIAN TRADISIONAL INDONESIA BERBASIS ANDROID
}

\author{
Resti Amalia \\ Teknik Informatika, Universitas Pamulang \\ Email: dosen00850@unpam.ac.id
}

\begin{abstract}
ABSTRAK
Pengenalan lagu dan tarian tradisional di Indonesia sangat penting untuk dikenalkan kepada generasi penerus bangsa. Dengan memperkenalkan berbagai lagu dan tarian daerah, bisa membangkitkan rasa nasionalisme dan rasa ke Bhineka-an. Perkembangan smartphone saat ini sangat pesat dan cepat, tidak hanya digunakan oleh pengguna sebagai media komunikasi, tetapi juga sebagai media informasi. Oleh karena itu, penulis berusaha membuat solusi pembelajaran lagu dan tarian tradisional yang praktis menggunakan smartphone android sebagai media informasinya. Keragaman tarian dan lagu daerah dari 31 propinsi bisa kita dapatkan didalam aplikasi ini. Aplikasi ini dapat berjalan dengan baik pada perangkat berbasis android dengan versi 4.0 keatas.
\end{abstract}

Kata Kunci: Android, Lagu, Tari, Tradisional.

\section{PENDAHULUAN}

Perkembangan smartphone saat ini berkembang pesat dan cepat, teknologi tidak hanya digunakan oleh pengguna sebagai media komunikasi, tetapi juga sebagai media informasi. Salah satunya smartphone yang berbasis android, android merupakan sistem perangkat mobile yang berkembang pesat pada saat ini.

Tari merupakan sesuatu yang bisa menyatukan berbagai hal hingga semua orang dapat menyelaraskannya atau menyesuaikan diri menurut cara-caranya sendiri.

Lagu tradisional atau lagu kedaerahan adalah lagu yang berasal dari suatu daerah tertentu dan menjadi populer karena dinyanyikan rakyatnya sendiri atau lainnya . Lagu daerah memiliki keunikan tersendiri. Keunikan tersebut dapat dilihat dari bahasa daerah yang digunakan, selain itu setiap contoh lagu daerah juga memiliki makna yang tersembunyi.

Mengingat remaja zaman sekarang lebih banyak menghabiskan waktunya dengan memilih bermain game dibandingkan belajar, sehingga wawasan mereka tentang kebudayaan negeri mereka sendiri menjadi sempit. Budaya bangsa Indonesia yang beraneka ragam ini merupakan jati diri yang dimiliki oleh bangsa Indonesia sehingga penting bagi remaja untuk mempertahankannya. Minimnya kepedulian masyarakat Indonesia akan lagu dan tari tradisional disebabkan oleh beberapa faktor seperti, kurangnya pengenalan dan pemahaman tentang lagu dan tari tradisional sejak dini, kurangnya ketersediaan dan minimnya tenaga ahli, remaja sekarang menganggap kesenian musik tradisional tidak mengikuti perkembangan zaman dan sudah tertinggal jauh dengan alat musik moderen yang sudah mulai merebut perhatian masyarakat Indonesia khususnya pada lingkatan remaja.

Berdasarkan latar belakang diatas, penulis mengajukan penelitian tugas akhir ini (skripsi) dengan judul "APLIKASI ENSIKLOPEDIA LAGU DAN TARIAN TRADISIONAL INDONESIA BERBASIS ANDROID".

\section{TEORI}

Lagu

Lagu daerah adalah lagu atau musik yang berasal dari suatu daerah tertentu dan menjadi populer dinyanyikan baik oleh rakyat daerah tersebut maupun rakyat lainnya. Bentuk lagu ini sangat sederhana dan menggunakan bahasa daerah atau bahasa setempat. Lagu daerah banyak yang bertemakan kehidupan sehari-hari sehingga mudah untuk dipahami dan mudah diterima dalam berbagai kegiatan rakyat. Pada umumnya pencipta lagu daerah ini tidak diketahui lagi alias noname (NN). Menurut sifat dan keberasalannya lagu daerah dibedakan menjadi dua. Lagu rakyat dan Lagu klasik. Lagu rakyat yaitu lagu yang berasal dari rakyat di suatu daerah. Lagu rakyat tersebar secara alami yang disampaikan secara lisan dan turun-temurun. Contoh lagu rakyat yaitu lagu yang dipakai untuk pernikahan, kematian, berladang, berlayar, menenun. Lagu klasik yaitu lagu yang dikembangkan di pusatpusat pemerintahan rakyat lama seperti ibukota 
kerajaan atau kesultanan. (Muhyiddin Al-Idrus, 2014).

\section{Tari}

Tari tradisional merupakan salah satu warisan budaya yang harus dilestarikan, namun yang berkembang saat ini justru tari tradisional mulai diabaikan bahkan dilupakan oleh generasi muda. Salah satu faktor yang menyebabkan masalah ini yaitu, anak-anak hingga kaum muda kini sudah lebih mengenal tarian modern daripada tarian tradisional. (Imron Wahyudi, 2015).

\section{Android}

Android merupakan sistem operasi berbasis Linux yang dirancang untuk perangkat seluler layar sentuh seperti Smartphone. Android awalnya dikembangkan oleh Android Inc, dengan dukungan finansial dari Google, yang kemudian membelinya pada tahun 2005. Sistem operasi ini dirilis secara resmi pada tahun 2007, bersamaan dengan didirikannya Open Handset Alliance, konsorsium dari perusahaan-perusahaan perangkat keras, perangkat lunak, dan telekomunikasi yang bertujuan untuk memajukan standar terbuka perangkat seluler. Ponsel Android pertama dijual pada bulan Oktober 2008. Menurut (Safaat H, Nazaudin, 2012), Android merupakan sistem operasi untuk telepon seluler yang berbasis Linux. Android menyediakan platform terbuka bagi para pengembang untuk menciptakan aplikasi mereka sendiri untuk digunakan oleh bermacam peranti bergerak. Android umum digunakan di Smartphone dan juga tablet PC. Fungsinya sama seperti sistem operasi Symbian di Nokia, iOS di Apple dan Blackberry OS. (Yanuar Supriyadi, 2014), menyatakan bahwa Android merupakan sebuah sistem informasi untuk perangkat mobile berbasis Linux yang mencakup sistem operasi, middleware dan aplikasi. Menurut (Edward Yeremias, 2011) mendefinisikan bahwa Android adalah sistem operasi untuk telepon seluler yang berbasis Linux.

Berdasarkan pengertian diatas, dapat ditarik kesimpulan bahwa Android merupakan sebuah sistem operasi untuk smartphone berbasis kernel Linux yang merupakan platform terbuka sehingga pengembang dapat dengan bebas mengembangkan aplikasi.

Seperti teknologi lainnya, Android muncul tidak langsung canggih seperti saat ini. Teknologinya yang bersifat open source, terus berkembang dan selalu terbuka untuk digunakan dan dikembangkan kapan saja. Mungkin inilah yang membuat Android begitu diminati.

\section{Metode Penelitian}

Metode penelitian yang digunakan dalam penelitian ini selain mencari literature yang berhubungan dengan tari dan lagu, juga melakukan tahapan pengembangan menggunakan model waterfall Nama model ini sebenarnya adalah "Linear Sequential Model". Model ini sering disebut juga dengan "classic life cycle" atau metode waterfall. Model ini termasuk ke dalam model generic pada rekayasa perangkat lunak dan pertama kali diperkenalkan oleh Winston Royce sekitar tahun 1970 sehingga sering dianggap kuno, tetapi merupakan model yang paling banyak dipakai dalam Software Engineering (SE). Model ini melakukan pendekatan secara sistematis dan berurutan. Disebut dengan waterfall karena tahap demi tahap yang dilalui harus menunggu selesainya tahap sebelumnya dan berjalan berurutan.

1. Communication (Project Initiation \& Requirements Gathering) Sebelum memulai pekerjaan yang bersifat teknis, sangat diperlukan adanya komunikasi dengan customer demi memahami dan mencapai tujuan yang ingin dicapai. mendefinisikan fitur dan fungsi software.

2. Planning (Estimating, Scheduling, Tracking) Tahap berikutnya adalah tahapan perencanaan yang menjelaskan tentang estimasi tugas-tugas teknis yang akan dilakukan, resiko-resiko yang dapat terjadi, sumber daya yang diperlukan dalam membuat sistem, produk kerja yang ingin dihasilkan, penjadwalan kerja yang akan dilaksanakan, dan tracking proses pengerjaan sistem.

3. Modeling (Analysis \& Design) Tahapan ini adalah tahap perancangan dan permodelan arsitektur sistem yang berfokus pada perancangan struktur data, arsitektur software, tampilan interface, dan algoritma program. Tujuannya untuk lebih memahami gambaran besar dari apa yang akan dikerjakan.

4. Construction (Code \& Test) Tahapan Construction ini merupakan proses penerjemahan bentuk desain menjadi kode atau bentuk/bahasa yang dapat dibaca oleh mesin. Setelah pengkodean selesai, dilakukan pengujian terhadap sistem dan juga kode yang sudah dibuat. 
5. Deployment (Delivery, Support, Feedback) Tahapan Deployment merupakan tahapan implementasi software ke customer, pemeliharaan software secara berkala, perbaikan software, evaluasi software, dan pengembangannya. (Pressman, 2015).

\section{PERANCANGAN}

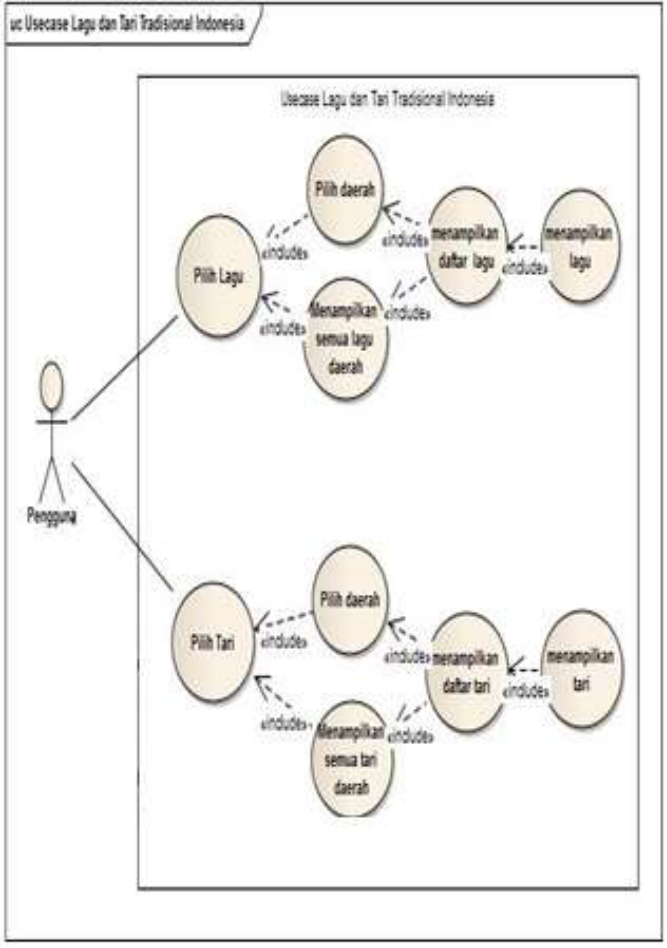

Gambar 3.2 Use case Diagram Lagu dan Tarian Tradisional Indonesia

\begin{tabular}{|l|l|l|}
\hline No & Deskripsi & \multicolumn{1}{|c|}{ Keterangan } \\
\hline 1. & $\begin{array}{l}\text { Use case } \\
\text { Lagu }\end{array}$ & $\begin{array}{l}\text { Pengguna dapat memilih } \\
\text { informasi dari daerah mana } \\
\text { lagu tersebut } \\
\text { Pengguna dapat melihat } \\
\text { detail lagu }\end{array}$ \\
\hline 2. & $\begin{array}{l}\text { Use case } \\
\text { Tari }\end{array}$ & $\begin{array}{l}\text { Pengguna dapat memilih } \\
\text { infomasi dari daerah mana } \\
\text { tari tersebut } \\
\text { Pengguna dapat melihat } \\
\text { detail tari }\end{array}$ \\
\hline
\end{tabular}

\section{HASIL DAN PEMBAHASAN}

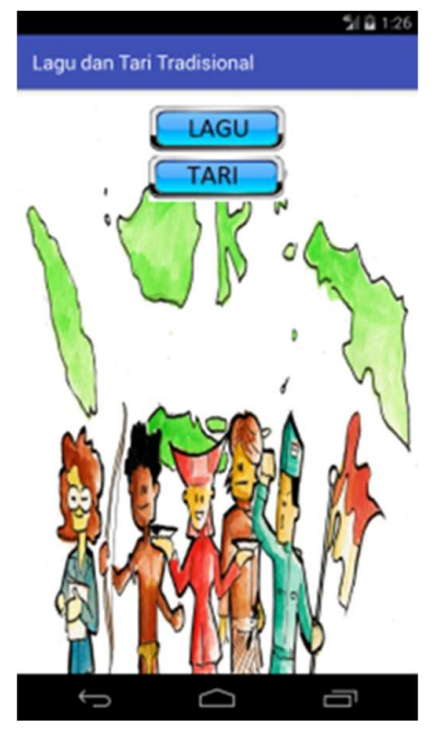

Gambar 4.1 Tampilan Home
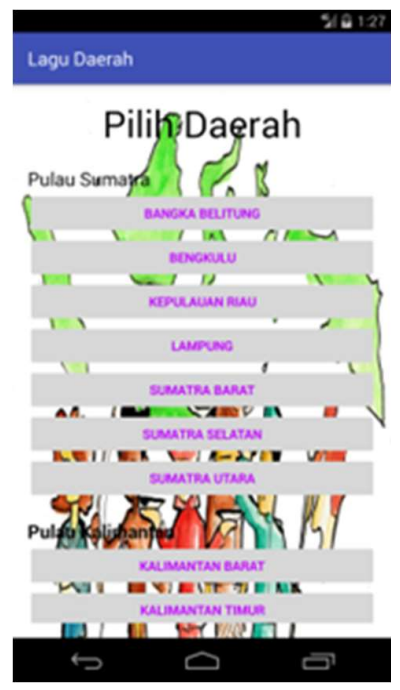

Gambar 4.2 Tampilan Halaman Lagu

Saat aplikasi berjalan pertama kali, maka aplikasi akan mengarahkan kita ke halaman splash dan menuju halaman utama, halaman utama berisi 2 tombol, yaitu tombol tari dan juga tombol lagu dimana jika salah satu tombol di klik, maka akan diarahkan ke halaman berikutnya.

Halaman berikutnya dari halaman lagu berisi daftar nama-nama lagu sesuai daerahnya yang bias pengguna gulir kebawah untuk melihat menu lagu sesuai daerahnya yang nanntinya autodirect ke google drive dimana file lagu berada. 


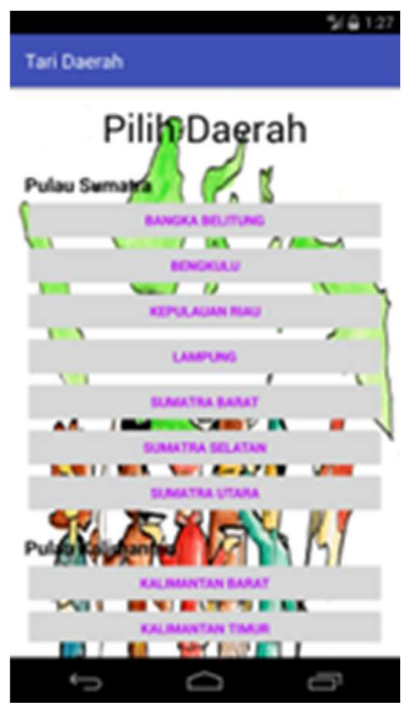

Gambar 4.3 Tampilan Halaman Tari

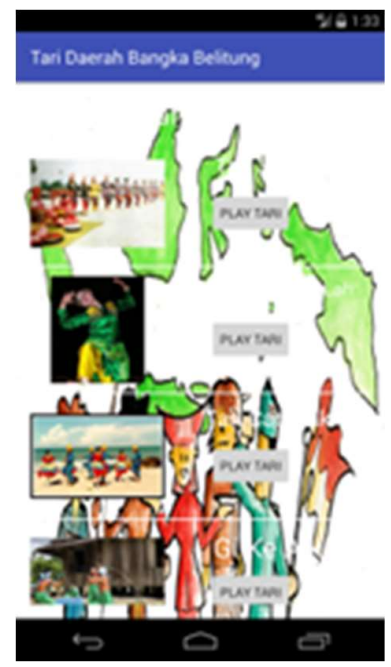

Gambar 4.4 Tampilan Halaman Tari Daerah

Sama seperti halaman pada halaman lagu. Jika tombol tari dihalaman utama diklik maka akan menuju kehalamn tari, halaman tari berisi daftar tari sesuai dengan nama daerahnya.

\section{PENGUJIAN}

1. Pengujian Black Box Menu Utama

Pada pengujian menu utama hal yang diujikan yaitu berupa memilih menu lagudan menu tari,. Untuk lebih jelasnya pada tabel 4.1 menunjukkan hasil dari pengujian menu utama.

Tabel 4. 1 Pengujian Black Box Menu

\begin{tabular}{|c|c|c|c|c|}
\hline No & Perintah & Yang Diharapkan & Pengamatan & Hasil \\
\hline \multirow{3}{*}{1.} & \multirow{3}{*}{$\begin{array}{c}\text { Memilih menu } \\
\text { lagu }\end{array}$} & $\begin{array}{c}\text { Dapat } \\
\text { menampilkan } \\
\text { daftar daerah }\end{array}$ & $\begin{array}{c}\text { Daftar daerah } \\
\text { dapat di } \\
\text { tampilkan sesuai } \\
\text { dengan yang } \\
\text { diharapkan }\end{array}$ & Diterima \\
\hline & & $\begin{array}{c}\text { Dapat } \\
\text { menampilkan } \\
\text { daftar lagu }\end{array}$ & $\begin{array}{l}\text { Daftarlagu dapat } \\
\text { di tampilkan } \\
\text { sesuai dengan } \\
\text { yang diharapkan }\end{array}$ & Diterima \\
\hline & & $\begin{array}{c}\text { Dapat } \\
\text { menampilkan lagu }\end{array}$ & $\begin{array}{c}\text { Lagu dapat di } \\
\text { tampilkan sesuai } \\
\text { dengan yang di } \\
\text { harapkan }\end{array}$ & Diterima \\
\hline
\end{tabular}

\section{Pengujian Black Box Menu Lagu}

Tabel 4.2 Pengujian Black Box Menu Lagu

\begin{tabular}{|c|c|c|c|c|}
\hline No & Perintah & Yang Diharapkan & Pengamatan & Hasil \\
\hline & & $\begin{array}{c}\text { Dapatmenampilkan } \\
\text { daftar daerah }\end{array}$ & $\begin{array}{c}\text { Daftar daerah dapat di } \\
\text { tampilkan sesuai dengan } \\
\text { yang diharapkan }\end{array}$ & Diterima \\
\cline { 3 - 5 } 1. & $\begin{array}{c}\text { Memilih menu } \\
\text { tani }\end{array}$ & $\begin{array}{c}\text { Dapatmenampilkan } \\
\text { daftar tari }\end{array}$ & $\begin{array}{c}\text { Daftar tari dapat di } \\
\text { tampilkan sesuai dengan } \\
\text { yang diharapkan }\end{array}$ & Diterima \\
\cline { 3 - 5 } & & $\begin{array}{c}\text { Dapatmenampilkan } \\
\text { video }\end{array}$ & $\begin{array}{c}\text { Video dapat ditampilkan } \\
\text { sesuai dengan yang } \\
\text { diharapkan }\end{array}$ & Diterima \\
\hline
\end{tabular}

3. Pengujian Black Box Menu Tari

Pada pengujian menu tari hal yang diujikan yaitu berupa memilih daerah, memilih tari, memainkan video. Untuk lebih jelasnya pada tabel 4.8 menunjukkan hasil dari pengujian menu tari.

Tabel 4.3 Pengujian Black Box Menu Tari

\begin{tabular}{|c|c|c|c|c|}
\hline No & Perintah & Yang Diharapkan & Pengamatan & Hasil \\
\hline \multirow{3}{*}{1.} & \multirow{3}{*}{$\begin{array}{c}\text { Memilih menu } \\
\tan \end{array}$} & $\begin{array}{l}\text { Dapatmenampillkan } \\
\text { daftar daerah }\end{array}$ & $\begin{array}{c}\text { Daftar daerah dapat di } \\
\text { tampilkan sesuai dengan } \\
\text { yang diharapkan }\end{array}$ & Ditenima \\
\hline & & $\begin{array}{c}\text { Dapatmenampillkan } \\
\text { daftar tan }\end{array}$ & $\begin{array}{c}\text { Daftar tari dapat di } \\
\text { tampilkan sesuai dengan } \\
\text { yang diharapkan }\end{array}$ & Diterima \\
\hline & & $\begin{array}{l}\text { Dapatmenampillkan } \\
\text { video }\end{array}$ & $\begin{array}{c}\text { Video dapat di tampilkan } \\
\text { sesuai dengan yang } \\
\text { diharapkan }\end{array}$ & Diterima \\
\hline
\end{tabular}

\section{KESIMPULAN}

Berdasarkan penelitian dan implementasi aplikasi ensiklopedia lagu dan tari tradisional Indonesia yang dilakukan, maka dapat dibuat kesimpulan bahwa :

1. Dengan adanya aplikasi tersebut mempelajari lagu dan tari tradisional Indonesia menjadi lebih mudah dengan menggunakan smartphone android, karena penggunaan smartphone saat ini tidak hanya digunakan sebagai media 
komunikasi, melainkan juga sebagai media informasi.

2. Dengan adanya aplikasi tersebut dapat memudahkan masyarakat dalam mengenal lagu dan tari tradisional Indonesia dengan menggunakan smartphone android. Cara kerja aplikasi ensiklopedia lagu dan tari tradisional Indonesia berbasis android dengan menggunakan smartphone. Halaman utama dari aplikasi ensiklopedia lagu dan tari tradisional Indonesia adalah menu lagu yang akan menampilkan daftar lagu dari 31 provinsi yang ada di Indonesia, menu tari yang akan menampilkan daftar tari dari 31 provinsi yang ada di Indonesia, menu tentang untuk menampilkan tentang aplikasi dan menu keluar untuk keluar dari aplikasi.

\section{DAFTAR PUSTAKA}

1412-9434, Jurnal Ilmiah Komputasi ISSN. (2013). Rancang Bangun Aplikasi Pembelajaran Budaya Indonesia Untuk Anak Sekolah Dasar Berbasis Android. Rancang Bangun Aplikasi Pembelajaran Budaya Indonesia Untuk Anak Sekolah Dasar Berbasis Android .

Edward Yeremias. (2011). Exploring Android On Your Own Pc. Yogyakarta: Penerbit Andi.

Felker D. (2013). Android Application Development for Dummies. Indianapolis: Wiley Publishing Inc.

http://ilmuseni.com. Retrieved Agustus 23, 2017, from http://ilmuseni.com: http://ilmuseni.com/senipertunjukan/senitari/fungsi-seni-tari

http://ilmuseni.com. Retrieved Agustus 23, 2017, from http://ilmuseni.com: http://ilmuseni.com/seni-pertunjukan/senitari/unsur-unsur-senitari

https://adiozh.com. Retrieved Agustus 23, 2017, from https://adiozh.com.

https://id.wikipedia.org. Retrieved Agustus 23, 2017, from:

https://id.wikipedia.org/wiki/Daftar_versi_An droid

Imron Wahyudi. (2015). Aplikasi Ensiklopedia Tarian Tradisional dan Sejarahnya Berbasis Android. Aplikasi Ensiklopedia Tarian Tradisional dan Sejarahnya Berbasis Android.

Kreibich, Jay A. (2010). Using SQLite. USA: O'Reilly Media Inc.

Lankhorst, M. D. (2007). Enterprise Architecture Development and Modelling Combining TOGAF and ArchiMate. Jerman.

M. Shalahuddin dan Rosa. (2010). Sun Microsystems.
Muhyiddin Al-Idrus. (2014). Pembuatan Aplikasi Kumpulan Lagu Daerah di Indonesia Berbasis Android. Pembuatan Aplikasi Kumpulan Lagu Daerah di Indonesia Berbasis Android .

Pressman, R. (2015). Rekayasa Perangkat Lunak : Pendekatan Praktisi Buku I. Yogyakarta: Andi.

Prof Dr Koentjaraningrat. (1963). Antropologi Indonesia.

R. A Sukamto dan M. Shalahuddin. (2013). Rekayasa Perangkat Lunak. Bandung: Informatika.

Robby Hidayat. (2008). Seni Pertunjukan Etnis Jawa, Ritus, Simbolisme, Politik, dan Problematikanya. Malang: Gantar Gumelar.

Safaat H, Nazaudin. (2012). Pemrograman Aplikasi Mobile Smartphone dan Tablet PC Berbasis Android. Bandung: Informatika Bandung.

www.pendidikanmu.com. Retrieved Agustus 23, 2017, from Pendidikanmu: http://www.pendidikanmu.com/2015/05/6jenis-lagu-nusantara-di-indonesia.html

Yakub. (2012). Pengantar Sistem Informasi. Yogyakarta: Graha Ilmu.

Yanuar Supriyadi. (2014). Semua Bisa Menjadi Programer Android. Jakarta: PT Elix Media Komputindo. 